\title{
Peranan Orangtua Dalam Pembinaan Akhlak Remaja di Kecamatan Nanggalo Kota Padang
}

\author{
Gheatasya Sagita Anjani', Ahmad Rivauzi ${ }^{2}$ \\ gheatasyasagita14@gmail.com¹, ahmadrivauzi@fis.unp.ac.id² \\ Universitas Negeri Padang ${ }^{1,2}$
}

\begin{tabular}{|c|c|}
\hline ART & \multirow{13}{*}{$\begin{array}{l}\text { ABSTRACT } \\
\text { Penelitian ini bertujuan untuk menjelaskan peran } \\
\text { orangtua dalam pembinaan akhlak remaja, dan } \\
\text { mendeskripsikan faktor pendukung dan penghambat } \\
\text { orangtua dalam pembinaan akhlak. Penelitian ini } \\
\text { berjenis penelitian lapangan dengan pendekatan } \\
\text { kualitatif. Sumber data diambil melalui dokumentasi, } \\
\text { observasi dan wawancara dengan tujuh informan. } \\
\text { Hasil penelitian menunjukkan bahwa peranan orang } \\
\text { tua dalam pembinaan akhlak remaja belum berjalan } \\
\text { secara maksimal, dikarenakan oleh beberapa faktor di } \\
\text { antaranya yaitu kurangnya pendidikan orangtua } \\
\text { tentang akhlakul karimah, kurangnya kesadaran } \\
\text { orangtua untuk memberikan contoh akhlak yang baik } \\
\text { di dalam kehidupan sehari-hari, dan faktor lingkungan } \\
\text { yang kurang mendukung remaja untuk memiliki } \\
\text { akhlak yang baik sehingga menjadi penyebab beberapa } \\
\text { kasus terjadi pada beberapa keluarga. Contoh kasus di } \\
\text { antaranya yaitu terdapat orangtua yang tersangkut } \\
\text { kasus sebagai bandar narkoba dan di dalam keluarga } \\
\text { tersebut juga terdapat salah seorang anak yang hamil } \\
\text { diluar nikah. Selain itu contoh permasalahan lain juga } \\
\text { ditemukan di keluarga berbeda, dimana orangtua } \\
\text { memberikan izin anaknya untuk berduaan dengan } \\
\text { teman lawan jenis di rumah. }\end{array}$} \\
\hline Article history: & \\
\hline stus 2021 & \\
\hline Revi & \\
\hline & \\
\hline Keywords: & \\
\hline rang tua, & \\
\hline Pembinaan Akhlak, & \\
\hline Remaja & \\
\hline Clonflict of Interest: & \\
\hline Non & \\
\hline Fundi & \\
\hline None & \\
\hline
\end{tabular}

Corresponding Author: Gheatasya Sagita Anjani, Department Islamic Education, Faculty of Social Science, Universitas Negeri Padang, Indonesia, Email: gheatasyasagita14@gmail.com Phone: +62 96$1810-9245$

(c) (†) Copyright(C2021, Author(s)

\section{Pendahuluan}

Orangtua merupakan pendidik utama serta awal untuk seorang anak, sebab dari merekalah anak mulai mendapatkan pembelajaran (Arief, 2002: 76). Pada setiap anak 
terdapat suatu dorongan dan daya untuk meniru. Dengan dorongan ini anak bisa mengerjakan sesuatu yang dikerjakan oleh ibu dan bapaknya. Oleh karena itu orangtua wajib jadi teladan untuk anak-anaknya. Dalam perihal ini sangat diharapkan kewaspadaan dan atensi yang besar dari orangtua. sebab masa meniru ini secara tidak langsung ikut membentuk sifat anak dimasa yang akan datang (Taubah, 2015: 2).

Jadi, suri teladan yang baik mempunyai dampak yang besar terhadap karakter anak (Suwaid, 2009: 139). Anak akan tumbuh dengan karakter yang sesuai dengan contoh yang diberikan oleh orangtuanya di dalam kehidupan sehari-hari. Anak tentu akan hidup dengan akhlak yang terpuji jika orangtuanya mengajarkan akhlak yang terpuji kepada anak tersebut. Kebalikannya, jika anak sering melihat perilaku yang menyimpang dan tidak baik dari orangtuanya, tentu anak tersebut juga akan tumbuh dengan perilaku yang menyimpang pula (Ulwan, 2013: 538).

Adapun umur remaja adalah umur yang rentan, yang mana remaja tersebut sangat bergantung kepada lingkungannya untuk menentukan akhlak mereka. Usia remaja 12-15 tahun adalah usia yang paling rentan dalam pertumbuhannya, karena pada usia ini sangat penting bagaimana cara remaja memandang dan menghadapi peristiwa-peristiwa yang ada di sekitarnya dan pandangan mereka tersebut akan menentukan perilakunya. Jadi, lingkungan memang menjadi faktor yang sangat penting untuk mempengaruhi perilaku remaja. Apabila lingkungannya baik, maka remaja tersebut akan besar kemungkinan untuk memiliki akhlak dan perilaku yang baik, dan begitu pula sebaliknya.

Islam telah menetapkan tata cara akhlak mulia. Akhlak terbagi menjadi beberapa bidang, antara lain akhlak terhadap Allah, diri sendiri, sesama (tetangga dan keluarga), dan lingkungan sekitar. Akhlak merupakan konsep kajian terhadap ihsan. Ihsan adalah ajaran tentang mensyukuri kehadiran Tuhan dalam hidup, dengan menghargai diri sendiri dan dihadapan Tuhan saat beribadah. Ihsan juga merupakan jenis pendidikan atau latihan untuk mencapai kesempurnaan islam (kaffah) dalam arti yang seluas-luasnya, sehingga Ihsan merupakan puncak tertinggi keislaman seseorang. Ihsan baru bisa terwujud setelah melewati dua tahapan pertama, yaitu keimanan dan keislaman (Marzuki, 2012: 9).

Kemerosotan moral masyarakat secara umum, khususnya Indonesia, akhir-akhir ini semakin mengkhawatirkan. Hal ini ditandai dengan semakin banyak kenakalankenakalan yang dilakukan oleh remaja, seperti tawuran yang sering kali terjadi diberbagai daerah yang dilakukan oleh pemuda bahkan pelajar, terjadinya perilaku bullying diberbagai sekolah-sekolah bahkan ada yang sampai melakukan pembunuhan. Selain itu, minimnya tatakrama dengan masyarakat dan khususnya terhadap orang tua menjadi bukti kemerosotan akhlak remaja pada saat ini.

Dalam hal ini peneliti menemukan kemerosotan akhlak remaja yang terjadi di lokasi penelitian, yaitu di RW XIII Kelurahan Surau Gadang Kecamatan Nanggalo Kota Padang. Di daerah tersebut banyak ditemukan remaja yang perilakunya sangat jauh dengan Akhlakul karimah yang sudah disyariatkan oleh agama Islam. Diantara kenakalan remaja tersebut yaitu kurangnya tatakrama terhadap orang yang usianya 
lebih tua, sering berkata-kata kasar, berpacaran, bahkan tidak jarang didaerah tersebut terdapat anak remaja yang hamil diluar nikah. Dalam penelitian juga terlihat ada sebagian orangtua yang tidak peduli terhadap penyimpangan-penyimpangan yang sudah dilakukan oleh anak-ananknya. Misalnya, terdapat sebagian orangtua yang tidak menegur anak mereka yang sudah jelas-jelas sedang berdua-duaan dengan teman yang bukan muhrimnya, mirisnya hal tersebut terjadi dirumah dan dirumah tersebut terdapat orangtua, akan tetapi remaja tersebut dengan leluasa berpacaran dan berpegang-pegangan. Padahal seharusnya disini orangtua membina anak mereka untuk memiliki akhlak yang sudah disyariatkan oleh agama islam. Melihat fenomena tersebut, akan diteliti bagaimana peranan orangtua dalam pembinaan akhlak remaja usia 12-15 tahun di RW XIII kelurahan surau gadang kecamatan nanggalo kota padang.

\section{Tinjauan Pustaka}

Akhlak adalah sifat yang tertanam dalam jiwa, dan dapat bertindak dengan mudah tanpa berpikir dan pertimbangan. Jika sifat-sifat tersebut menghasilkan perbuatan baik menurut akal dan syariat Islam disebut akhlak yang baik, dan jika sifat-sifat tersebut menghasilkan akhlak yang buruk disebut akhlak yang buruk (Ilyas, 2006: 2). Secara istilah, akhlak adalah sistem nilai yang mengatur sikap dan pola perilaku manusia di muka bumi. Sistem nilai yang dimaksud adalah ajaran Islam, dengan Al-Qur'an dan Sunnah Nabi sebagai sumber nilai, dan ijtihad sebagai metode berpikir Islam (Alma \& Syahidin, 2009: 235).

Pada dasarnya tujuan akhlak adalah untuk mengajarkan manusia bagaimana menjalin hubungan dengan Tuhan Pencipta, dan bagaimana menjalin hubungan dengan sesama manusia. Hakikat dan ajaran akhlak adalah niat yang kuat untuk melakukan atau tidak melakukan sesuatu menurut keridhaan Allah (Tim Penyusun MKD IAIN Sunan Ampel, 2011: 107).

Dapat disimpulkan dari teori-teori di atas bahwa akhlak adalah sifat yang tertanam dalam diri seseorang, yang dapat menyebabkan perilaku spontan tanpa pemikiran dan pertimbangan pelaku. Jika perilakunya baik, maka perilaku tersebut disebut akhlak yang baik. Namun, jika ada perbuatan jahat, maka disebut perbuatan yang tercela. Nata (2008) mengemukakan bahwa ada dua faktor yang mempengaruhi pembinaan akhlak pada anak, yaitu faktor internal yakni potensi fisik, intelektual dan mental (spiritual) yang dibawa anak sejak lahir, serta faktor eksternal, diantaranya adalah keluarga, sekolah, dan tokoh masyarakat. Melalui kerjasama yang baik antara ketiga lembaga pendidikan tersebut, akan terbentuk aspek kognitif (pengetahuan), emosional, dan psikomotor dari ajaran yang sudah diajarkan pada anak. Hal inilah yang disebut dengan manusia seutuhnya (Nata,2008: 171).

Orangtua memiliki banyak sekali peran yang dapat membentuk anak-anak mereka menjadi anak yang baik dalam segala hal termasuk dalam segi akhlak. Menurut Duryat (2016), Peran orangtua dalam kehidupan seorang anak adalah membiasakan berakhlak mulia, beribadah, dan disiplin. Misalnya membiasakan anak- 
anak makan bersama keluarga, sehingga mereka tahu akhlak sopan santun menghargai orang lain, membiasakan untuk melakukan ibadah-ibadah lain, seperti shalat, puasa, dan lainnya, dan membiasakan kedisiplinan sebagai penyeimbang terhadap kebebasan yang diberikan kepada anak agar ia terlatih dan dapat terkontrol dengan menerapkan bentuk tingkah laku sesuai ajaran islam (Duryat, 2016: 112114).

Orang tua adalah panutan bagi anak, karena setiap anak mengidolakan orang tuanya pada awalnya, dan semua perilaku orang tua ditiru oleh anak. Orangtua adalah pendidik yang pertama dan utama bagi anak-anaknya. Orang tua disebut sebagai pendidik utama karena pengaruhnya yang besar dan karena merekalah yang mendidik anak-anaknya. Pendidikannya diluar rumah itu hanya sekedar membantu orangtua saja sebagai pendidik utama (Tafsir, 2002: 7).

Jadi, orangtua harus menjalankan perannya dengan baik dalam melakukan pembinaan akhlak anak, terutama remaja. Monks dkk (1989) mengemukakan dalam Ali \& Asrori (2018) bahwa remaja sebenarnya tidak memiliki posisi yang jelas. Mereka tidak lagi termasuk dalam kelompok anak-anak dan orang dewasa. Oleh sebab itu, remaja sering disebut sebagai tahap "mencari identitas". remaja masih belum mampu menguasai dan mengerahkan fungsi fisik dan psikis yang terbaik. Periode remaja merupakan masa perkembangan seseorang yang memiliki potensi sangat besar di dalam kehidupannya (Ali \& Asrori, 2018: 9-10).

Menurut Papilia dan Olds dalam Putro (2017), masa remaja adalah masa transisi perkembangan antara masa kanak-kanak dan dewasa, yang biasanya dimulai pada umur 12 atau 13 tahun dan berakhir pada umur akhir belasan tahun atau awal dua puluh tahun. Disamping itu, Anna Freud dalam Putro (2017) berpendapat bahwa pada masa remaja berlangsung proses perkembangan yakni perkembangan psikologi seksual, dan perubahan dalam hubungan dengan orangtua dan juga cita-cita mereka (Putro, 2017: 25).

Menurut Agustiani (2009), pertumbuhan remaja dibagi menjadi tiga bagian, yaitu remaja awal, remaja pertengahan, dan remaja akhir. Namun, yang akan peneliti jadikan sebagai objek penelitian disini adalah remaja pada tingkatan pertama yaitu remaja awal, yang mana remaja awal ini berumur 12-15 tahun. Peneliti tertarik mengambil remaja awal menjadi objek yang akan diteliti karena penyimpanganpenyimpangan yang terjadi, sering dilakukan oleh remaja pada tingkat awal ini. Karna remaja pada tingkat awal ini masih sangat labil dan masih sangat sulit untuk membedakan yang baik dengan yang tidak baik. Objek yang akan diteliti nantinya akan di interview bersama dengan orangtuanya, sehingga peneliti mendapatkan seumber sesuai dengan yang diinginkan.

Memberi pengajaran akhlakul karimah merupakan peran yang sangat penting dilaksanakan oleh orangtua dalam pembinaan akhlak remaja. Remaja awal merupakan usia yang sangat labil, karena pada usia ini remaja baru saja meninggalkan perannya sebagai anak-anak dan berusaha untuk tidak bergantung kepada orangtua mereka (Agustiani,2009: 29). Pada usia ini sebenarnya para remaja sangat bingung akan perannya apakah masih melakukan peran sebagai anak-anak 
atau sudah melakukan peran sebagai orang dewasa, ini menyebabkan remaja bertindak labil dalam kehidupan sehari-hari. Maka dari itu, sangat dipentingkan peran orangtua dalam membentuk akhlak dan perilaku remaja agar remaja tersebut tidak terjerumus kepada akhlak yang tidak baik dan tidak disyariatkan oleh agama islam.

\section{Metodologi}

Penelitian ini adalah studi lapangan (filed research), dengan pendekatan kualitatif. Populasi dalam penelitian ini yaitu penduduk di RW XIII Kelurahan Surau Gadang Kecamatan Nanggalo Kota Padang. Peneliti mengambil populasi penelitian yang terdiri atas ketua RW, orangtua, remaja, dan beberapa masyarakat sekitar. Sementara itu, yang ditetapkan sebagai sampel dalam penelitian ini adalah remaja umur 12-15 tahun beserta orangtuanya. Peneliti mengambi informan dari ketua RW, Orangtua, remaja, dan masyarakat sekitar. Dalam penelitian ini, peneliti sendiri bertindak sebagai alat. Teknik pengumpulan data dalam penelitian ini yaitu melalui observasi, wawancara, dan dokumentasi. Kemudian, data dianalisis dengan langkah (1) Reduksi data, (2) Penyajian data, (3) Diagram kesimpulan. Teknik pengabsahan data yang peneliti gunakan dalam penelitian ini adalah triangulasi teknik. Triangulasi teknik adalah kredibilitas data uji dilakukan dengan menggunakan teknik yang berbeda untuk memeriksa data dari sumber yang sama (Sugiyono, 2010: 274).

\section{Hasil dan Pembahasan}

Berdasarkan hasil observasi dan wawancara yang sudah peneliti lakukan di RW XIII Kelurahan Surau Gadang Kecamatan Nanggalo Kota Padang, peneliti melihat bahwa hanya sebagian kecil orangtua yang menjalankan perannya dalam pembinaan akhlak remaja, dari tujuh orang informan yang peneliti dapatkan, hanya dua orang diantaranya yang benar-benar menjalankan peran dalam pembinaan akhlak kepada remaja. Beberapa orangtua yang belum menjalankan perannya secara maksimal di daerah ini memiliki berbagai macam sebab dan latar belakang yang berbeda-beda, diantaranya adalah kurangnya pendidikan orangtua dalam bidang akhlak, kurangnya kesadaran akhlak pada diri orangtua itu sendiri, dan ada juga yang disebabkan oleh masalah keluarga yang tidak kunjung usai pada keluarga tersebut sehingga ini akan berdampak kepada anak-anak mereka.

Keluarga yang berada di RW XIII Kelurahan Surau Gadang Kecamatan Nanggalo ini memiliki latar belakang berbeda-beda yang menyebabkan permasalahan yang mereka alami di dalam setiap keluarga itu tentunya berbeda-beda pula. Dari hasil observasi dan wawancara yang sudah peneliti lakukan, peneliti melihat bahwa kurangnya kesadaran akhlak yang terjadi di RW XIII Kelurahan Surau Gadang ini disebabkan oleh permasalahan yang melatar belakangi beberapa keluarga. Contoh kasus atau permasalahan yang ada di daerah ini yang menyebabkan tidak berjalannya peran orangtua dalam pembinaan akhlak remaja yaitu adanya salah satu orangtua yang terlibat kasus narkoba, yang tentunya kasus ini menyebabkan orangtua tersebut 
harus masuk ke dalam penjara dan secara otomatis orangtua tersebut tidak dapat menjalankan perannya sebagai orangtua kepada remaja.

Perilaku dan akhlak remaja yang mendapatkan peranan orangtua nya dalam kehidupan sehari-hari tentunya berbeda dengan remaja yang tidak mendapatkan peran dan perhatian dari orangtua mereka, dari sini lah timbul permasalahanpermasalahan akhlak remaja yang ada di masyarakat sehingga menyebabkan beberapa orangtua dan masyarakat sekitar merasa bahwa lingkungan tersebut tidak baik untuk pertumbuhan akhlak remaja.

Jadi, semestinya orangtua memang harus menjalankan peran dan memberikan pengajaran kepada remaja melalui pembiasaan dalam kehidupan sehari-hari, misalkan orangtua mengajak anak untuk melaksanakan shalat lima waktu, menghormati orang yang lebih tua, dan berbicara dengan kata-kata yang baik dan sopan didalam kehidupan sehari-hari. Namun, hal-hal yang penulis jabarkan diatas tersebut masih jarang ditemukan pada orangtua yang terdapat di RW XIII Kelurahan Surau Gadang Kecamatan Nanggalo Kota padang, meskipun banyak orangtua yang kurang menjalankan perannya di daerah tersebut, akan tetapi ada juga beberapa orangtua yang sudah melakukan perannya dengan baik dan berusaha mengajarkan remaja untuk berbuat baik. Hal tersebut menyebabakan minimnya akhlakul karimah yang dimiliki oleh remaja yang berada di RW XIII Kelurahan Surau Gadang Kecamatan Nanggalo Kota Padang. Meskipun demikian, masih ada beberapa remaja yang memiliki akhlak yang baik di RW XIII Kelurahan Surau Gadang ini dan berusaha mengajak teman-temannya untuk selalu berbuat baik.

1. Sebagai madrasah pertama bagi anak-anak mereka, terdapat berbagai macam peran yang harus dilaksanakan oleh orangtua dalam pembinaan akhlak remaja.dalam penelitian ini, peneliti fokus kepada tiga peran yang harus dilaksanakan oleh orangtua dalam membina akhlak remaja, peran-peran tersebut diantaranya adalah memberi pendidikan akhlakul karimah kepada remaja, membangun kesadaran akhlak, dan juga melakukan pengawasan perilaku terhadap remaja. Memberi Pendidikan Akhlak Kepada Remaja

Berdasarkan hasil observasi dan wawancara, peranan orangtua dalam memberi pendidikan akhlak yang baik kepada remaja belum berjalan secara maksimal. Ini disebabkan karena kurangnya pengetahuan orangtua tentang akhlakul karimah, hal ini disebabkan karena rata-rata orangtua di daerah tersebut hanya berpendidikan SMA. Selain kurangnya pengetahuan orangtua, penyebab lain yang menyebabkan kurang berjalan secara maksimalnya peran orangtua dalam memberi pendidikan akhlak adalah karena kebanyakan orangtua belum memberikan waktu khusus untuk menyampaikan pengajaran tentang akhlak yang baik kepada remaja.

Mengenai materi-materi yang diberikan dalam melakukan pembinaan akhlak, hanya dua dari tujuh orangtua saja yang benar-benar memberikan pengajaran tentang akhlak kepada remaja. Dua dari tujuh orangtua yang benar-benar memberikan pengajaran tentang akhlak didaerah ini biasanya memberikan pengajaran dan materi-materi tentang akhlak yang baik, berperilaku sopan santun, 
menghormati orang yang lebih tua, bertutur kata yang baik, dan juga selalu mengajak remaja untuk melaksanakan shalat lima waktu didalam kehidupan sehari-hari.

Berikut akan penulis deskripsikan kutipan hasil wawancara dengan beberapa informan terkait peran memberi pendidikan akhlak kepada remaja:

Tabel 1. Petikan Wawancara Tentang Memberi Pendidikan

\begin{tabular}{|c|c|c|}
\hline Tema & Informan & Petikan Wawancara \\
\hline \multirow{4}{*}{$\begin{array}{l}\text { Memberi } \\
\text { waktu } \\
\text { khusus } \\
\text { dalam } \\
\text { pendidikan } \\
\text { akhlak }\end{array}$} & 2 & $\begin{array}{l}\text { Saya tidak memberikan waktu khusus untuk memberikan } \\
\text { pengajaran akhlak,... }\end{array}$ \\
\hline & 5 & Kalau untuk memberikan waktu khusus sih saya jarang,... \\
\hline & 6 & $\begin{array}{l}\text { Saya tidak pernah memberikan waktu khusus untuk } \\
\text { memberikan nasihat tentang akhlak kepada anak saya,... }\end{array}$ \\
\hline & 7 & $\begin{array}{l}\text { Saya tidak terlalu banyak memberikan waktu khusus untuk } \\
\text { memberikan pengajaran tentang akhlak kepada anak } \\
\text { saya,... }\end{array}$ \\
\hline \multirow{2}{*}{$\begin{array}{l}\text { Materi- } \\
\text { materi yang } \\
\text { diberikan } \\
\text { dalam } \\
\text { pembinaan } \\
\text { akhlak }\end{array}$} & 1 & $\begin{array}{l}\text { Saya biasanya memberikan nasihat dan masukan agar } \\
\text { perilaku anak saya tidak melenceng dari ajaran agama } \\
\text { islam, seperti sopan santun, berperilaku yang baik, bergaul } \\
\text { dengan teman-teman yang baik, dan semacamnya,... }\end{array}$ \\
\hline & 3 & $\begin{array}{l}\text { Saya sering memberikan nasihat dan pendidikan- } \\
\text { pendidikan tentang agama kepada anak saya, misalnya } \\
\text { pengajaran tentang akhlak yang baik, menghormati orang } \\
\text { yang lebih tua, dan selalu berkata-kata yang baik,... }\end{array}$ \\
\hline
\end{tabular}

2. Membangun Kesadaran Akhlak

Hasil observasi yang peneliti dapatkan terkait peran orangtua dalam membangun kesadaran akhlak kepada remaja dapat dinilai kurang maksimal, hal ini dapat dilihat bahwa orangtua hanya memberikan nasihat dan pengajaran tentang bertutur kata yang baik didalam kehidupan sehari-hari kepada remaja, akan tetapi orangtua tersebut tidak mempraktikkan hal tersebut pada dirinya, masih banyak ditemukan orangtua yang menggunakan bahasa yang kurang baik didalam kehidupan sehari-hari, seperti berkata-kata kasar, bernada tinggi ketika berbicara, dan lain sebagainya.

Di daerah ini juga ditemukan beberapa orangtua yang bermasalah yang menyebabkan orangtua tersebut kurang memiliki kesadaran dalam berakhlak yang baik, seperti orangtua yang tersangkut kasus sebagai bandar narkoba yang mana kasus tersebut menyebabkan dirinya harus masuk ke dalam penjara, di sini bisa ditarik kesimpulan bahwa orangtua tersebut tidak memiliki kesadaran akhlak di dalam dirinya, selain memberikan keluarganya nafkah yang haram, secara otomatis orangtua ini tidak memberikan contoh yang baik kepada anak-anaknya untuk berakhlak yang mulia.

Berdasarkan hasil wawancara yang sudah peneliti lakukan, orangtua pada umumnya membangun kesadaran akhlak anak mereka dengan cara memberikan contoh yang baik. Namun ketika peneliti melakukan observasi, peneliti melihat bahwa masih ada sebagian orangtua yang belum memiliki kesadaran akhlak di dalam dirinya sehingga akan sulit untuk membangun kesadaran akhlak kepada remaja, hal ini ditandai dengan beberapa kasus yang sudah peniliti jabarkan di atas. Berikut akan 
Gheatasya Sagita Anjani dan Ahmad Rivauzi: Peranan Orang tua dalam Pembinaan...

penulis deskripsikan kutipan hasil wawancara dengan beberapa informan terkait peran membangun kesadaran akhlak:

Tabel 3. Petikan Wawancara Tentang Membangun Kesadaran Akhlak

\begin{tabular}{lcl}
\hline \multicolumn{1}{c}{ Tema } & Informan & \multicolumn{1}{c}{ Petikan Wawancara } \\
\hline $\begin{array}{l}\text { Membangun } \\
\text { Aksadaran }\end{array}$ & 3 & $\begin{array}{l}\text { Saya membangun kesadaran akhlak kepada anak saya } \\
\text { itu misalnya dengan memberikan contoh-contoh yang } \\
\text { baik,... }\end{array}$ \\
\cline { 2 - 4 } & 4 & $\begin{array}{l}\text { Memberi contoh sangat penting dalam pendidikan } \\
\text { akhlak anak,... }\end{array}$ \\
\cline { 2 - 4 } & 5 & $\begin{array}{l}\text { Kalau kita hanya sekedar memberikan pengajaran saja } \\
\text { kepada anak itu rasanya kurang efektif, jadi saya } \\
\text { membangun kesadaran akhlaknya itu dengan cara } \\
\text { memberikan contoh,... }\end{array}$ \\
\cline { 2 - 5 } & $\begin{array}{l}\text { Saya biasanya kalau dirumah itu memberikan contoh } \\
\text { untuk selalu bertanggungjawab dan peduli terhadap } \\
\text { sekitar, }\end{array}$ \\
\hline
\end{tabular}

3. Pengawasan Perilaku

Berdasarkan hasil observasi dan wawancara, sebagian besar orangtua menyatakan sudah melakukan pengawasan perilaku. Namun pada kenyataan yang terjadi, peneliti melihat bahwa pengawasan perilaku yang dilakukan oleh sebagian besar orangtua tersebut kurang tegas sehingga menyebabkan peran pengawasan perilaku dalam pembinaan akhlak remaja ini dapat dinilai kurang maksimal. Berikut akan penulis deskripsikan kutipan hasil wawancara dengan beberapa informan terkait peran pengawasan perilaku:

Tabel 4. Petikan Wawancara Tentang Pengawasan Perilaku

\begin{tabular}{lcl}
\hline \multicolumn{1}{c}{ Tema } & Informan & \multicolumn{1}{c}{ Petikan Wawancara } \\
\hline $\begin{array}{l}\text { Pengawasan } \\
\text { perilaku }\end{array}$ & 2 & $\begin{array}{l}\text { Saya mengawasi anak saya dengan cara menegur dan } \\
\text { menasehati jika dia melakukan kesalahan. }\end{array}$ \\
\cline { 2 - 3 } & 4 & $\begin{array}{l}\text { Saya biasanya mengawasi perilaku dengan membatasi jam } \\
\text { pulang malamnya. }\end{array}$ \\
\cline { 2 - 4 } & 5 & $\begin{array}{l}\text { Anak saya itu suka tidak nurut dan mendongkol kalau } \\
\text { dilarang-larang, jadi agak susah mengawasinya,... }\end{array}$ \\
\cline { 2 - 4 } & 6 & $\begin{array}{l}\text { Biasanya saya menasehati baik-baik anak saya itu kalau } \\
\text { dia melakukan kesalahan, tapi jika masih diulangi, } \\
\text { langsung saya marahi. }\end{array}$ \\
\hline
\end{tabular}

Peran orangtua dalam pembinaan akhlak remaja di RW XIII Kelurahan Surau Gadang Kecamatan Nanggalo Kota Padang ini belum berjalan secara maksimal diakibatkan oleh orangtua yang masih belum melaksanakan perannya dalam pembinaan akhlak remaja. Hal tersebut terjadi tentunya disebabkan oleh berbagai macam latar belakang masalah keluarga yang terdapat dalam beberapa keluarga, seperti masalah kurangnya pendidikan orangtua terhadap akhlakul karimah, dan juga permasalahan lain yang timbul dari beberapa kasus yang terdapat didaerah ini. 
Beberapa kasus yang mana di daerah tersebut terdapat salah satu orangtua dari remaja yang peneliti jadikan sebagai objek penelitian merupakan seorang narapidana yang tersangkut kasus sebagai bandar narkoba. Berdasarkan hasil observasi dan wawancara yang sudah peneliti lakukan, hal tersebut tentunya tidak baik terhadap kesehatan mental dan pertumbuhan akhlak anak. Sebagaimana wawancara yang sudah peneliti lakukan dengan anak dari orangtua yang bersangkutan "Papa sudah beberapa kali keluar masuk penjara, kadang malu juga sama teman-teman karna papa harus masuk penjara". masuknya salah satu orangtua ke dalam penjara menyebabkan remaja tersebut kehilangan peran salah satu orangtuanya dalam kehidupan seharihari.

Selain permasalahan di atas, peneliti juga menemukan permasalahan yang ditemukan dikeluarga yang lain, yaitu kurangnya pendidikan akhlak yang dimiliki oleh orangtua. Hal ini didukung oleh kenyataan yang peneliti temukan di lapangan yaitu adanya orangtua yang membiarkan anak mereka untuk berdua-duaan dengan lawan jenis di rumah, padahal di dalam islam sudah dilarang keras untuk menjauhi zina dan dilarang untuk berdua-duaan dengan orang yang bukan muhrim, akan tetapi orangtua tersebut memberikan tempat kepada anaknya untuk berdua-duaan dengan teman yang bukan muhrimnya, bahkan orangtua yang bersangkutan juga menggunakan pakaian yang tidak sopan ketika ada laki-laki yang bukan muhrimnya tersebut sedang berada dirumah, orangtua tersebut menggunakan pakaian yang terbuka. Tentunya orangtua tersebut tidak menjalankan perannya dalam pembinaan akhlak remaja, ini disebabkan karena kurangnya pengetahuan orangtua terhadap agama dan pendidikan akhlak.

Ada beberapa dampak dari kurang maksimalnya peranan orangtua dalam pembinaan akhlak terhadap remaja. Diantara dampak-dampak tersebut adalah terjadinya pergaulan bebas dikalangan remaja, kurangnya sopan santun dan akhlakul karimah pada remaja di daerah tersebut, banyak remaja yang menggunakan katakata yang tidak baik dalam pergaulan. Dampak-dampak tersebut bisa membuat lingkungan menjadi tidak baik untuk pembentukan akhlak, dan juga remaja yang sebelumnya mendapatkan didikan akhlak yang baik dari orangtuanya bisa sewaktuwaktu memiliki akhlak yang buruk karena dipengaruhi oleh lingkungan sekitar.

Dalam melaksanakan peran-perannya dalam pembinaan akhlak remaja tentunya orangtua menemukan faktor pendukung dan faktor penghambat. Diantara faktor pendukung yang ditemui yaitu faktor keadaan keluarga di rumah dan juga didikan dari sejak usia dini yang diberikan orangtua kepada anak sehingga anak bisa lebih menerima ajaran-ajaran dan nasihat-nasihat yang diberikan oleh orangtua karena anak tersebut sudah terbiasa menerima pengajaran-pengajaran tersebut sedari kecil.

Selain faktor pendukung, orangtua juga menemui faktor-faktor penghambat yang membuat orangtua tersebut sulit untuk memberikan pembinaan akhlak kepada remaja, yaitu diantaranya adalah kurangnya pendidikan dan pengetahuan orangtua tentang akhlakul karimah, kurangnya kesadaran akhlak di dalam diri orangtua itu sendiri, faktor lingkungan yang kurang baik dan juga kurangnya kemampuan 
Gheatasya Sagita Anjani dan Ahmad Rivauzi: Peranan Orang tua dalam Pembinaan...

orangtua untuk menggunakan strategi-strategi dan teknik-teknik dalam melakukan pembinaan akhlak.

\section{Simpulan}

Berdasarkan hasil penelitian dan pembahasan yang penulis lakukan dan telah penulis paparkan, maka disimpulkan bahwa:

Peranan orangtua dalam pembinaan akhlak remaja di RW XII Kelurahan Surau Gadang Kecamatan Nanggalo Kota Padang belum berjalan secara maksimal, karena disebabkan oleh berbagai macam faktor, seperti kurangnya pendidikan orangtua tentang akhlakul karimah, kurangnya kesadaran orangtua untuk memberikan contoh akhlak yang baik di dalam kehidupan sehari-hari, faktor lingkungan yang kurang mendukung remaja untuk memiliki akhlak yang baik dan juga permasalahanpermasalahan lain yang dihadapi oleh beberapa keluarga yang menyebabkan peran orangtua dalam pembinaan akhlak remaja di daerah ini belum berjalan secara baik dan maksimal.

Dalam menjalankan peran dalam pembinaan akhlak remaja, para orangtua di daerah ini memiliki berbagai faktor pendukung dan penghambat, diantara faktor pendukung yang paling banyak ditemui adalah faktor keadaan keluarga di rumah dan juga didikan dari sejak usia dini, sedangkan faktor penghambat yang paling banyak dialami oleh orangtua dalam melakukan pembinaan akhlak kepada remaja adalah kurangnya pendidikan dan pengetahuan orangtua tentang akhlakul karimah, kurangnya kesadaran akhlak di dalam diri orangtua itu sendiri, faktor lingkungan yang kurang baik dan juga Kurangnya kemampuan orangtua untuk menggunakan strategi-strategi dan teknik-teknik dalam melakukan pembinaan akhlak.

\section{Referensi}

Agustiani, Hendri. 2009. Psikologi Perkembangan. Bandung: Refika Aditama.

Ali, Mohammad., \& Asrori, Mohammad. 2018. Psikologi Remaja. Jakarta: PT Bumi Aksara.

Alma, Buchari., \&Syahidin. 2009. Moral dan Kognisi Islam. Bandung: CV. Alfabeta.

Arief, Armai. 2002. Pengantar Ilmu dan Metodologi Pendidikan Islam. Jakarta: Ciputat Pers.

Duryat, Masduki. 2016. Paradigma Pendidikan Islam. Bandung: Alfabeta.

Ilyas, Yunahar. 2006. Kuliah Akhlak. Yogyakarta: Pustaka Pelajar Offset.

Marzuki. 2012. Pembinaan Karakter Mahasiswa Melalui Pendidikan Islam di Perguruan Tinggi Umum. Yogyakarta: Ombak.

Nata, Abuddin. 2008. Akhlak Tasawuf. Jakarta: PT Raja Grafindo Persada.

Putro, Khamim Zarkasih. 2017. Memahami Ciri dan Tugas Perkembangan Masa Remaja. Jurnal Aplikasi Ilmu-Ilmu Agama, 17(01)

Suwaid, Muhammad Nur Abdul Hafizh. 2009. Prophetic Parenting Cara Nabi Mendidik Anak. Yogyakarta: Pro-U Media

Sugiyono. 2010. Metode Penelitian Pendidikan dan R \& D. Bandung: Alfabeta.

Taubah, Mufatihatut. 2015. Pendidikan Anak Dalam Keluarga Perspektif Islam. Jurnal Pendidikan Agama Islam, 03(01). 
Tim Penyusun MKD IAIN Sunan Ampel. 2011. Akhlak Tasawaf. Surabaya: IAIN Sunan Ampel Press.

Tafsir, Ahmad. 2002. Pendidikan Agama Dalam Keluarga. Bandung: PT. Rosadakarya.

Ulwan, Abdullah Nashih. 2013. Tarbiyatul Aulad Pendidikan Anak Dalam Islam. Jakarta: Khatulistiwa Press. 